\title{
Research on the Suggestions of Democratic Parties in Qiqihar City to Promote Urban Development
}

\author{
Changfang Lu \\ Qiqihar Medical University, Qiqihar City, Heilongjiang Province, 161006, China
}

Keywords: Qiqihar City; Democratic parties; Offering advice and suggestions; administration and discussion of state affairs

\begin{abstract}
The improvement of democratic parties' ability to participate in the administration and discussion of state affairs plays an important role in the development of a city. This paper focused on analyzing the existing problems in democratic parties in Qiqihar City to offer advice and suggestions, and participating in administration and discussion of state affairs. Then, the paper proposed effective countermeasures to promote the development of Qiqihar City.
\end{abstract}

\section{Introduction}

With the development of society and economy, and the continuous improvement of scientific and democratic decision-making, the traditional ideas, contents and mechanisms of participating in administration and discussion of state affairs cannot meet the needs of the modern society. Democratic parties need to be innovative in the formulation of public policies with the times, which is a new test for them. By analyzing how the democratic parties in Qiqihar City offer advice and suggestions, the author can find the existing problems in the process and formulate effective coping strategies to promote the stable development of Qiqihar City.

\section{Existing Problems when Democratic Parties in Qiqihar City Offer Advice and Suggestions}

\subsection{Insufficient subjective awareness}

In terms of the main body who participates in the administration and discussion of state affairs, the democratic parties in Qiqihar City are not enthusiastic in participating in the formulation of urban development policies and mechanisms, and their capability of mechanism innovation needs to be improved. The lack of recognition of the role of participation in mechanism innovation can be seen in three aspects: first, democratic parties "dare not" participate in the mechanism innovation and are always overtaken by misgivings and fear or swayed by considerations of gain and loss; second, they are "unwilling" to participate in mechanism innovation and think the mechanism innovation is a thankless thing, which may offend someone, so it is clever for them to pretend not to know it; third, they are "bad" at participating in the mechanism innovation. Some democrats have realized the necessity of mechanism innovation. However, due to insufficient understanding of the actual situation, they cannot propose scientific, reasonable and operable suggestions on the mechanism innovation. There appears the problem that democratic parties cannot concentrate on crucial points in the mechanism innovation when they participate in administration and discussion of state affairs.

\subsection{Defective innovation mechanism}

The basic functions of the democratic parties are to participate in the administration and discussion of state affairs, to exercise democratic supervision and to provide social services. How to effectively fulfill these functions requires the research on the working mechanism innovation of the democratic parties in participating in the administration and discussion of state affairs. The document to Central Committee of the CPC has repeatedly stressed the need to step up mechanism innovation for democratic parties to participate in the administration and discussion of state affairs, 
but this is only a matter of principle. There is no operational example nationwide. Despite the establishment of a number of systems in the mechanism innovation for democratic parties in Qiqihar City to participate in the administration and discussion of state affairs, there is not a mechanism that allows interaction within and outside the party. Although many leading cadres in democratic parties have recognized the shortcomings of the mechanism innovation, they all agree that the mechanism innovation is not perfect.

\subsection{Imperfect working standards in participating in the administration and discussion of state affairs}

The functions of participating in the administration and discussion of state affairs, and democratic supervision undertaken by the democratic parties are stipulated in the constitutional laws of China. This is binding in terms of institution. However, the democratic parties in Qiqihar City have not performed their functions in the working mechanism innovation in participating in the administration and discussion of state affairs well. The reason is that there lacks perfect working standards for the democratic parties in China to perform their functions. In China, the effect of mechanism innovation for democratic parties to participate in the administration and discussion of state affairs often depends on the acceptance of the ruling party, which determines the great uncertainty of the effectiveness of the democratic parties in the mechanism innovation in participating in the administration and discussion of state affairs. To ensure the effectiveness of the mechanism innovation, institutions and legal protection are needed.

\subsection{Less obvious group advantages in participating in the administration and discussion of state affairs}

Whether democratic parties can give full play to their group advantages is an important aspect to exam their capability to participate in the the administration and discussion of state affairs, which directly affects the level of working mechanism innovation in this process. As can be seen from the survey, the group advantages of democratic parties in Qiqihar City in participating in the the administration and discussion of state affairs are not obvious. This is mainly due to the relatively small number of members of the democratic parties who hold fewer positions in the government departments in Qiqihar City and they lack understanding of the government's actions. This leads to their inability to make constructive comments and suggestions and their opinions and proposals are not in-depth. Eventually, These proposals are denied by the government.

\subsection{Limitations of the self-building of democratic parties}

Most primary-level organizations of the democratic parties have their own limitations. For instance, personnel and funding problems have not been well solved. From the questionnaire about the participation of democratic parties in public policy in Qiqihar city, it can be seen that there lacks talents in working mechanism innovation in participating in the administration and discussion of state affairs in Qiqihar City at present. Most of them are intellectuals. From the perspective of social structure, it is simple. Members of the democratic parties have some limitations. They have little or no emphasis on the appeals and aspirations of grassroots people. As a result, their proposals and opinions are not persuasive and will not be accepted. Some ordinary and young members of the democratic parties have less experience in their work and they are small-minded. Some of them are not enthusiastic about participating in administration and discussion of state affairs. This leads to many problems when democratic parties participate in administration and discussion of state affairs.

\section{Strategies to Improve the Quality of Proposals of Democratic Parties in Qiqihar City}

\subsection{To strengthen the study of political theory}

In participating in the administration and discussion of state affairs, all democratic parties in Qiqihar City must first adhere to the multi-party cooperation system and political consultation system under the leadership of the CPC, study Deng Xiaoping Theory in depth, Thoughts of Three Represents, Scientific Outlook on Development and the Xi Jinping's Socialist Ideology with 
Chinese Characteristics in the new era. They should learn and understand these ideas well and recognize the advanced nature of the Chinese Communist Party and the superiority of the socialist system from the bottom of his heart. They will support the CPC's ruling status internally and actively strengthen its own capabilities and aspirations for the benefit of society to offers advice and suggestions to the modernization of the country . All democratic parties should conscientiously study the cultural and political contents of the national policies, routes, guidelines and so on. They should also learn the knowledge of various disciplines related to their participation in administration and discussion of state affairs to raise their ability to center around and serve the overall situation; they should vigorously promote their learning in the participating parties, and explore and summarize the new experience, methods and theories of participating in the administration and discussion of state affairs in the new era. It is necessary to build a politically determined, ideologically competent and plain living team with solid theories in participating in administration and discussion of state affairs.

\subsection{To establish guarantee mechanism for democratic parties to participate in the administration and discussion of state affairs}

The democratic parties in Qiqihar City should firmly establish the idea of participating in the administration and discussion of state affairs. In the objective circumstance where there are tedious things for some democratic party members, it is necessary to strengthen the cooperation among the various departments and agencies of the democratic parties. This is also a prerequisite guarantee for the democratic parties to participate in administration and discussion of state affairs. The members of democratic parties should constantly study the political, economic and cultural knowledge, actively broaden their horizons, emancipate their minds, conduct work research at the grass-roots level, listen to the opinions of the masses, reflect the voice of non-Party members in participating in administration and discussion of state affairs, and demonstrate their ability and achievements in participating in administration and discussion of state affairs to gain more social understanding and recognition. In addition to the financial and material resources that democratic parties need, they also need some experts to help them collect information, write research reports and transform achievements in order to enhance their ability to participate in administration and discussion of state affairs, and offer advice and suggestions so as to better promote the development of Qiqihar City.

\subsection{To standardize related mechanisms for democratic parties to participate in administration and discussion of state affairs}

In order to improve the quality of the participation of administration and discussion of state affairs of democratic parties in Qiqihar City, it is necessary to standardize the mechanism of participating in administration and discussion of state affairs, strengthen the sense of responsibility and regard the achievements of participating and discussing the state affairs of party members as an important part of assessment. Members who do well will be recognized and rewarded. This plays an important role in mobilizing the enthusiasm of members of the democratic parties to involve in the formulation of public policies. Democrats often spend a lot of money on their research activities. In the meantime, researchers need to spend a great deal of time and energy in conducting in-depth research and transforming achievements. This requires to regulate the work of party members in order to mobilize their enthusiasm to participate in the administration and discussion of state affairs. At the annual conference of participating in the administration and discussion of state affairs, they fully affirm those who have performed outstanding research and achievements in special investigations and studies, promote their work experience and set an example. Commendations should be given to those members of the democratic parties who have made outstanding achievements in participating in the administration and discussion of state affairs to give a better play to the role played by the democratic parties in Qiqihar City to promote the sound development of the city. 


\subsection{To make full use of the group advantages of the democratic parties}

In order to enhance the ability of democrats to offer advice and suggestions and promote the steady development of the city, Qiqihar City must take the democratic party as a platform and fully mobilize the initiative, constructiveness and enthusiasm of all democratic parties, streamline the channels of information and communication, and integrate all resources to give play to the advantages of the democratic parties. Through democratic special investigation reports, proposals, opinions, criticisms and suggestions, the city should expand the scope of the democratic parties' participation in administration and discussion of state affairs. It is necessary to take investigation and inspection as a link so that all sectors can give full play to their professional strengths and put forward their opinions and suggestions. It is necessary to let all sectors fully understand their own feelings with their proposals, social conditions and public opinions as their carrier. It is important to pay particular attention to issues that are hidden, difficult and hard to solve, so as to give full play to the important role played by group of democratic parties in participating in the administration and discussion of state affairs to promote the long-term development of Qiqihar City.

\subsection{To strengthen the team construction of democratic parties in participation in the administration and discussion of state affairs}

The mechanism of training qualified personnel of democratic parties in Qiqihar City plays an important role in raising their level in participating in the administration and discussion of state affairs. A team with high-quality cadres in the democratic parties often can play a more effective role in participating in the administration and discussion of state affairs. Therefore, it is imperative to strengthen team construction of political parties and personnel of political parties in the administration and discussion of state affairs and pay attention to the cultivation of qualified personnel so as to ensure more specialization of the internal political team of democratic parties. On one hand, it is necessary to provide a platform for democratic parties to participate in administration and discussion of state affairs, pay attention to their interest, hobbies and expertise and give full play to their respective strengths and talents. Moreover, it is necessary to choose members who are brave, good at and enthusiastic about participating in administration and discussion of state affairs, set up a excellent team and enable them to take the lead in participating in the administration and discussion of state affairs. On the other hand, it is important to discover qualified personnel, continuously enrich the new forces within the democratic parties and provide human resources for the participation and deliberation of democratic parties in state affairs. It is also necessary to develop more experts and personnel outside the party and make acquaintances with non-party personnel through investigation and research. They should also be invited to join the ranks of the democratic parties and gradually establish a team of qualified personnel for democratic parties so that they can continuously improve their ability and level in participating in administration and discussion.

\section{Conclusions}

To sum up, the democratic parties in Qiqihar City should strengthen their team building, improve the working mechanism for participating in the administration and discussion of state affairs, correct their work attitudes, and have a scientific understanding of their party when they offer advice and suggestions, so as to provide effective suggestions to the development of Qiqihar City, to give full play to its own role of participating in the administration and discussion of state affairs and promote the harmonious and stable development of the city.

\section{Acknowledgements}

Project source: Qiqihar Soft Science Research Project.

Title of the project: Suggestions of Democratic Parties in Qiqihar City to Promote Urban Development.

Subject number: RKX-201523. 


\section{References}

[1] Wan Fang, Yang Hao and Wang Li. A Problem Research on Offering Advice and Suggestions of Democratic Parties in Anshan City [J]. Journal of Liaoning Institute of Socialism, 2013 (01): 44-47.

[2] Cui Beijun. A Research and Thinking on Strengthening the Ability Construction of Democratic Parties in Participating in the Administration and Discussion of State Affairs [J]. Journal of Shanxi Institute of Socialism, 2015 (03): 31-36.

[3] Liao Sheng. An Analysis of the Point of democratic Parties in Offering Advice and Suggestions [J]. Democracy Monthly, 2017 (10): 12-13.

[4] Wang Chunmei. A Discussion on how to Do a Good Job in Offering Advice and Suggestions of Democratic Parties in the Construction of Ecological Civilization [J]. Journal of Shaanxi Institute of Socialism, 2014 (02): 30-32 + 64.

[5] Tian Xiaoyu. A Research on the Path of Strengthening the Consultation Capacity of Democratic Parties from the Perspective of Political Parties Consultation [J]. Journal of Chongqing Institute of Socialism, 2016, 19 (02): 25-31.

[6] Cui Beijun. A Research on Strengthening the Capacity-building of Democratic Parties to Participate in Administration and Discussion of State Affairs - A Case Study of Bengbu [J]. Journal of Liaoning Administration College, 2015 (08): 29-34. 